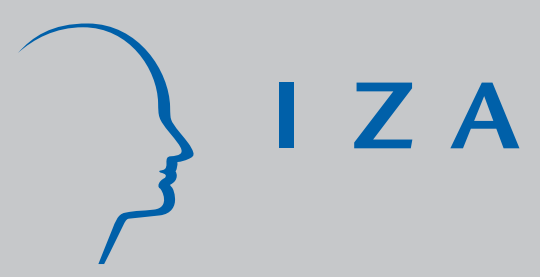

IZA DP No. 3549

The Role of Educational Choice in Occupational Gender Segregation: Evidence from Trinidad and Tobago

Sandra Sookram

Eric Strobl

J une 2008 


\title{
The Role of Educational Choice in Occupational Gender Segregation: Evidence from Trinidad and Tobago
}

\author{
Sandra Sookram \\ SALISES, University of the West Indies \\ Eric Strobl \\ Ecole Polytechnique Paris, \\ SALISES and IZA \\ Discussion Paper No. 3549 \\ June 2008 \\ IZA \\ P.O. Box 7240 \\ 53072 Bonn \\ Germany \\ Phone: +49-228-3894-0 \\ Fax: +49-228-3894-180 \\ E-mail: iza@iza.org
}

\begin{abstract}
Any opinions expressed here are those of the author(s) and not those of IZA. Research published in this series may include views on policy, but the institute itself takes no institutional policy positions.

The Institute for the Study of Labor (IZA) in Bonn is a local and virtual international research center and a place of communication between science, politics and business. IZA is an independent nonprofit organization supported by Deutsche Post World Net. The center is associated with the University of Bonn and offers a stimulating research environment through its international network, workshops and conferences, data service, project support, research visits and doctoral program. IZA engages in (i) original and internationally competitive research in all fields of labor economics, (ii) development of policy concepts, and (iii) dissemination of research results and concepts to the interested public.
\end{abstract}

IZA Discussion Papers often represent preliminary work and are circulated to encourage discussion. Citation of such a paper should account for its provisional character. A revised version may be available directly from the author. 


\section{ABSTRACT \\ The Role of Educational Choice in Occupational Gender Segregation: Evidence from Trinidad and Tobago*}

We analyse the role of educational choice on the degree of occupational segregation in Trinidad and Tobago during a period in which educational policies intent on equating gender opportunities in education were implemented. To this end we utilise waves of the Trinidad and Tobago labour force survey over the period 1991-2004. Our results show that while educational segregation has fallen substantially over our sample period, this has not translated into less occupational segregation. This suggests that the educational policy has not been sufficient to combat occupational segregation. However, results at a more disaggregated level show that experiences have been heterogeneous across educational and occupational groups.

JEL Classification: $\quad$ I21, J16, J24

Keywords: educational choice, occupational segregation, gender

Corresponding author:

Eric Strobl

Department of Economics

Ecole Polytechnique

91128 Palaiseau Cedex

France

E-mail: eric.strobl@shs.polytechnique.fr

\footnotetext{
* We are very grateful to the Trinidad and Tobago Central Statistics Office for providing access to the data used in the analysis. Comments from participants at the 2006 Conference of the Caribbean Studies Association are also much appreciated.
} 


\section{Section I: Introduction}

The segregation of men and women into different occupations continues to be one of the most enduring aspects of labour markets in both developed and developing countries alike. Importantly such occupational segregation has substantial consequences for gender discrimination since 'female type' jobs are generally characterized by lower pay and worse working conditions. ${ }^{1} \quad$ It is not surprising then that attempts to address segregation in employment have also had a long history in policymaking; see, for example, the International Labor Organization (ILO) convention on Discrimination (Employment and Occupation, 1958, No. 111). However, certainly while legislation directly prohibiting discrimination in employment is a pertinent element in its elimination, it is important to also realize that pre- and post- labour market entry decisions and opportunities regarding the level and type of education of individuals will themselves have an impact on the potential job opportunities available. ${ }^{2}$ Thus addressing gender inequalities in education may constitute another potentially important policy measure; see, for instance, Dolado et al (2004).

In this paper we explicitly examine the role of educational choices on occupational gender segregation in the context of such a supply-side policy using the case study of Trinidad and Tobago (T\&T). More specifically, while the T\&T Constitution forbids discrimination based on gender, but without defining $\mathrm{it}^{3}$, there had been no explicit legislation prohibiting discrimination in employment prior to $2000 .{ }^{4,5}$ In terms of gender education, in contrast, explicit

\footnotetext{
1 Arguably, effective policies in this regard are particularly important for developing countries, where the female labour force is now being viewed as a key component to economic development strategies, as portrayed, for instance, by the third Millennium Development Goal by the World Bank; see World Bank (2003).

${ }^{2}$ Educational choices may of course themselves be a consequence of discrimination in terms of family and societal gender preferences.

${ }^{3}$ This would protect women from discrimination with respect to legal statutes and public authorities.

4 The relevant legislation was the Equal Opportunity Act, 2000 (No. 69). Preceding this legislation, Trinidad and Tobago ratified two acts, in 1970 the ILO Convention Concerning Discrimination In Respect of Employment and Occupation (No. 111) and in 1997 the ILO Convention (No. 100), which calls for equal remuneration for men and
} 
policy steps towards gender equality were taken much earlier. That is, while the law that guides the course of education in Trinidad and Tobago, the Education Act of 1966, did not refer to gender based discrimination, the Education Policy Paper, which prescribed educational policy during the period 1993-2003, explicitly attempted to guide the educational system towards gender equality; see National Report on Development of Education in Trinidad and Tobago (2004). For instance, part of the initiative formed by this policy involved the development of a gender neutral curriculum by ensuring that males and females do not partake in only gender traditional subjects and training. For example, prior to this policy initiative, there would be timetabled classes during the week where a class in a co-educational school would be divided into males and females, where the former would take Industrial Arts classes (woodworking, metal work, technical drawing, etc) and the latter would do Home Economics (cooking, sewing, home management etc). Under the new policy directive the curriculum and timetable were restructured so that all students would be doing both Home Economics and Industrial Arts. Furthermore, from a more general perspective one should note that Trinidad and Tobago is a signatory of the 2000 Dakar Framework for Action and thus has committed itself to attaining certain goals, two of which in particular are the need for equitable access to education for females and the elimination of gender disparities in primary and secondary education. Given that other studies have shown that gender discrimination in the labour market in $\mathrm{T} \& \mathrm{~T}$ is considerable $^{6}$, the education policy changes implemented provide a good case study with which to assess whether such policies coincide with changes in occupational segregation.

women for work of equal value, but did not introduce any national legislation to ensure the implementation of the guidelines of these.

${ }^{5}$ While the Trinidad and Tobago Constitution did forbid discrimination based on gender, it contained no explicit definition.

${ }^{6}$ For example, the study on wage discrimination by Olsen and Coppin (2001) showed that in 1993 the male-female income differential was 19\%. Also, a cross-country study of occupational segregation in Latin America and the Caribbean over three decades, 1970-1990, Gammage (1998) found that there was a slight decrease in segregation in all countries except Trinidad and Tobago. 
While there are a number of studies examining occupational gender segregation in various labour markets ${ }^{7}$, only a few have addressed the issue of the role of educational choices in motivating such sorting. Deutsch et al (2001) calculate a segregation index for different educational categories for three Latin American countries and find that occupational segregation is much more severe among the less educated. In a seminal paper Borghans and Groot (1999) [henceforth BG] developed a decomposition of an occupational segregation index which allows one to explicitly investigate the link between educational and occupational sorting. More precisely, they decompose occupational segregation into its pre- and post-sorting components, where the former refers to the extent to which different educational distributions across gender cause different occupational distributions and the latter refers to sorting into occupations conditional on this, and how these are linked in the sense that the latter may or not may not reenforce segregation. Using Dutch data they discover that educational pre-sorting is a major cause of occupational segregation.

Here we employ the BG decomposition, which as to date has not been used in a developing country context, to waves of the Trinidad and Tobago labour force survey over the years 1991-2004, i.e., a time period encompassing the implementation of the aforementioned educational policy change. Our data set is arguably particularly suited to the task at hand since it allows for the classification of educational qualifications beyond the typical grouping, such as level and/or number of years of schooling completed. More precisely, we have detailed information on the field of the highest level of schooling and training completed, which allows for a much more meaningful categorization of educational qualification in terms of its relevance for occupational segregation. We use this information in conjunction with detailed occupation codes to calculate the occupational and educational segregation indices proposed by BG.

\footnotetext{
${ }^{7}$ See, for instance, Anker and Hein (1986) and Blau and Ferber (1992) for studies explicitly on developing countries.
} 
Another contribution of our paper is that we propose a simple method to calculate standard errors on the BG indices, thus allowing one to evaluate their statistical significance rather than just their size, as has been done in the past.

The remainder of the paper is organized as follows. In the following section we describe our data set. Section III outlines the segregation index decomposition methodology. The results derived from employing this methodology on our data are described in Section IV. Concluding remarks are provided in the final section.

\section{Section II: Data Set}

Our data source is the Continuous Sample Survey of Population (CSSP) for T\&T. The CSSP was designed as a multi-purpose household survey in 1963 with its primary objective being to provide up-to-date data on the labour force characteristics of the population of Trinidad and Tobago on a continuing basis. As such it has served as the primary source for aggregate statistics on the labour market, collecting a wide array of labour market relevant information on members of the households surveyed. With regard to the current paper we use information from the fourteen years available to us, namely 1991 to 2004, although we excluded 1997 since the size of the sample taken in that year was only a fraction of that in all other years.

In assembling a representative sample for each year and comparing segregation for these there are several factors to consider. A primary issue is that one would not want results to be driven by a specific choice of quarter and hence any seasonal factors in consideration, therefore a selection of observations across all four quarters is desirable. Moreover, since the CSSP is a rotating panel where households are interviewed three times using the whole year, it would mean 
utilizing several observations per individual. ${ }^{8}$ Unique household identifiers allow us to follow households over time and we thus included only the first observation of any household in any year in assembling the sample. For any given year there is no more than one observation for the employed, which is roughly equally spread over the four quarters. Overall, this resulted in a sample each year of approximately 4,000 households covering around 6,500 employed individuals.

The two main pieces of information of interest for purposes of this paper are the occupational and educational background of those employed in our constructed sample. In terms of education we have, as is usual in these types of data sets, data on an individual's highest level of educational attainment as it falls within 6 categories (ex: primary, lower vocational, higher secondary, etc.). More importantly, however, the CSSP also collects detailed information on the field of the highest level of training as it falls within 5 digit code categories. With these two variables at hand we categorized educational qualification into 37 categories, as listed in Table 2. These can be appropriately grouped into those with Primary, Lower General Secondary, Higher General Secondary, Lower Vocational, Intermediate Vocational, Higher Vocational, and Academic Education. An employed person's occupation in the CSSP is given at the four-digit level and we similarly categorized these into 48 categories, which are listed in Table 5. These can then be grouped into Lower, Intermediate, and Higher Occupations categories. One should note that our categorization was based on trying to mimic the categorization used by BG and what seemed appropriate in the T\&T context. ${ }^{9}$

\section{Section III: Methodology}

\footnotetext{
8 After the first inclusion in the panel, a household is interviewed one year later for the second time, and finally three months thereafter.

${ }^{9}$ BG divided their data into 54 educational and 49 occupational types.
} 


\section{Measures of Segregation}

We follow BG and define occupational segregation over $m$ different occupations as:

$O S=\theta \sum_{j=1}^{m}\left|\frac{F_{. j}}{F_{.}}-\frac{M_{. j}}{M_{.}}\right|=\sum_{i=1}^{m} O S_{j}$

$\theta \equiv \frac{F M}{T^{2}}$

where $F_{j}$ and $M_{j}$ are the number of females and males in occupation $j$ of $m$ different categories, respectively, $F$ and $M$ are their aggregate equivalents, and $T=F+M$. One should note that occupational segregation defined as above is an adjusted version of the popular Duncan and Duncan (1955) dissimilarity index, where the parameter $\theta$ serves to control for the fact that changes required to equalize male and female distributions within occupations will require changes in the occupational distribution itself. As such it ranges between 0 and 1 and measures the extent to which males and females work in different occupations, where a higher value indicates higher segregation.

In a similar manner one can define educational segregation for $n$ different educational categories:

$E S=\theta \sum_{i=1}^{n}\left|\frac{F_{i}}{F_{.}}-\frac{M_{i}}{M_{.}}\right|=\sum_{i=1}^{n} E S_{i}$

where $F_{i}$ and $M_{i}$ are the number of females and males in education group $i$, respectively. As with $O S$, ES ranges between 0 and 1 and measures the extent to which the educational backgrounds of men and women are different, where higher values indicate greater segregation.

In order to compare these indices across sub-groups they need to be adjusted by the relative size of each group:

$E S_{i}^{r e l}=\theta\left|\frac{F_{i}}{F}-\frac{M_{i .}}{M}\right| \frac{T}{T_{i .}}$ 
$O S_{j}^{r e l}=\theta\left|\frac{F_{f}}{F}-\frac{M_{j}}{M}\right| \frac{T}{T_{j}}$

where one may want to note that the only difference of these to (2) and (3) is that they are defined over sub-groups of categories and are adjusted by the relative size of the cells to be comparable across categories.

One can define the total segregation with respect to each education/occupation cells, TS, as:

$T S=\theta \sum_{i=1}^{n} \sum_{j=1}^{m}\left|\frac{F_{i j}}{F}-\frac{M_{i j}}{M}\right|$

In investigating how educational segregation `spills over’ to occupational segregation it is important to realize that once educational choices are made there are several possibilities to consider that can occur. First, there may also be a compensating tendency in the transition from school to the labour market, termed reintegration, R. For example, females with a typical 'female' type education might find employment in the same job type as men who followed a typical 'male' type of education. Thus, the difference between TS and OS will depend on how much of this reintegration process takes place:

$\mathrm{OS}=\mathrm{TS}-\mathrm{R}$

where the detailed definition of $\mathrm{R}$ is given in the Appendix. There are also those occupational choices that move segregation towards a more equal distribution, referred to as the decreases $D$, where males and females with the same educational background take up similar occupations. Finally, there are those that induce a movement away from a more equal distribution, i.e., the increases $I$, where males and females with the same educational choice end up in different job types. One should note that both of these serve as movements away from ES, but the latter will 
induce an increase, while the former will tend to decrease OS. Thus occupational segregation is related to $E S$ by ${ }^{10}$ :

$O S=E S+I-D-R$

where the precise technical formulas for $I$ and $D$ are given in the Appendix. One should note that, since $I$ and $D$ are conditional on educational choice, (8) implies that $E S$ is relevant for $O S$ only in the sense that men and women are not reintegrated. Using $R$ one can thus define an index of the impact of ES on $O S$ as:

$I M P A C T=(1-R / E S) * 100$

The lower this index, the less ES matters for $O S$ and hence this index can be taken as a proxy of how inequality in educational choices spill over into occupational segregation.

On a more general note, one may want to point out that the indices above serve merely as descriptive statistics of the extent of OS and ES and their relationship, but do not lend themselves to isolating what economic factors may be driving these. In other words, they can be used to isolate statistical trends within an economic and/or policy context, but cannot provide a test of what exact role such a context may have played.

\section{Statistical Significance}

Since our data are only a sample of the total employed population in any year one needs to asses the statistical significance of our segregation indices. In this regard we follow Deutsch et al (2001) and Boisso et al (1994) and resort to bootstrap methods to generate standard errors of our point estimates. More precisely, bootstrapping consists of taking random subsets of the data and computing the index under consideration for each of these and then calculating the standard error. Since the accuracy of the boostrap estimators will increase with the number of sub-samples drawn and must be big enough to be representative of the population which one is

\footnotetext{
${ }^{10}$ For further details of the derivation see BG.
} 
trying to estimate, we chose 500 samples of size equal to the number of observations of the original sample. One may want to note that BG did not assess the statistical significance of their calculated segregation indices.

\section{Section IV: Results}

Aggregate Trends

In Table 1 we report measures of aggregate $O S$ and its components and the bootstrapped standard errors for each year of our sample. First of all one may want to note that all indices turn out to be statistically significant by standard levels and hence are measured with considerable precision. It is also noteworthy that for a comparable year, 1993, the size of ES and $O S$ are similar to those found by BG with their Dutch data, indicating that segregation may not differ widely across middle income and high income countries. In terms of the trends of ES over our sample period one finds that there has been a substantial decrease over our sample period, particularly since 1994. Thus within our educational categories the distribution of men relative to women has become more equal since the early 1990s. One should note that this coincides with the implementation of the Educational Policy Paper, which for the first time implemented specific policy measures aimed at eliminating inequality in education across gender. However, as can be seen from the calculated $O S$ this fall in ES has only translated in a marginal decrease in gender segregation in employment, thus increasing the gap between ES and OS.

The decomposition of the various components of $O S$ in equation (8) can provide some insight into what is driving the growing wedge between pre-sorting and segregation in employment. In particular, one discovers that $I$ has increased substantially while $D$ has fallen marginally over our sample period. This suggests that, conditional on educational choice in aggregate the degree to which women have moved into more 'male type' jobs has marginally 
fallen while at the same time the degree to which women have moved into more 'female type' employment has increased over time. At the same time, as shown by the marginal fall in $R$, the rising discrepancy between $I$ and $D$ was not compensated for in any meaningful way by reintegration, where females with a typical 'female type' education might find employment in the same jobs as men who followed a typical 'male type' of education. Because of this lack of greater reintegration, the fall in ES sorting had little impact over time on aggregate $O S$, as indicated by the relative stability of the IMPACT index. Rather ES continues to be an important determinant of OS, roughly driving around 80 per cent of it. ${ }^{11}$

Educational Segregation by Group

Our results in Table 1 indicate that educational sorting has fallen substantially in aggregate (from 23.1 to 12.8 ). It is also of interest to determine whether such experience has been homogenous across our different educational categories. As a first step we depict the simple share of females and their change over time in our various educational categories in Table 2. Accordingly, there have been considerable changes in the share of females in educational groups over time. For instance, females have substantially increased their share in the lowest of the educational categories and now have a greater share in the more male type educational groups, such as in the Police Force. In the higher educational groups women also are now more prominent in what were traditionally more male type educational backgrounds, such as the more technical subjects (ex: Medical Laboratory) and those geared towards achieving more management level jobs (ex: Management and Public Administration).

We next report the measures of relative ES from (4) and their bootstrapped standard errors for the beginning and the end of our sample period in Table 3. For convenience sake we have multiplied these values by negative one for those categories in which more men than

\footnotetext{
${ }^{11}$ BG found the impact of ES on $O S$ to be of similar degree for the Netherlands.
} 
women have the particular educational background. One should also note that there are certain education types which do not have values for both years. For example, the educational categories 'Service' in the 'Higher General Secondary Education' group has values for only 1991, whereas 'Social Work and Counseling' in both the 'Higher Vocational Education' and 'Academic Education' groups has values for only 2004. This is likely as a result of changes in the offer of training types across time.

Proceeding to our actual results, in terms of educational types which are dominated by a greater number of males, we find that our results are roughly in line with a priori expectations. More precisely, one mostly finds that males dominate in the more technical educational groups and those that are traditionally male, such as the Defense Services. Importantly, however, one discovers considerable heterogeneous experiences across educational categories. For example, in categories such as Teacher Training ${ }^{12}$ (Academic Education), educational segregation can be as high as 66 per cent. Notably these happen to be female dominated educational groups. In contrast, in some others there is no statistically significant segregation in terms of educational choice - see, for example, Administrative and Legal in the Higher Vocational Education category.

Comparing the indices at the beginning and the end of our sample periods shows that in some cases there have been notable changes over time. For instance, initially segregated Transport and Communication (Intermediate Vocational Education) is no longer significant. In contrast, there are a number of initially non-segregated categories that are now characterized by a gender bias in composition but originally were not; see, for example, Crafts, Industry, and Technical (Higher General Secondary Education). Finally, while for many categories the extent

12 Data on teacher training in Trinidad and Tobago indicates that 121 males and 446 females were enrolled at the two teachers' training colleges in Trinidad and Tobago (National Report on the Development of Education in Trinidad and Tobago, 2004) 
of segregation has remained relatively stable, there are few notable exceptions in which there were drastic increases. For instance, in the male dominated Medical Science, Dentistry and Veterinary Sciences (Academic Education) segregation has nearly doubled.

With regard to these results by educational group one worry may be that many of these will consist of small samples and hence could potentially introduce a bias into the calculation of our standard errors. ${ }^{13}$ Unfortunately, as noted by Scholz (2007), it is not possible to precisely investigate the small sample properties of non-parametric estimators where there are no assumptions about the underlying distributional properties analytically, as is the case with our indices. Nevertheless, as a rough check we examined the sample size of those cells to be insignificant relative to the average sample size of cells in that year. However, there appeared to be no clear correlation between significance and sample size. For instance, in 1991 if we exclude the Primary and Lower Secondary Education groups, which are the largest, the insignificant cells had an average of 126 observations, while the significant ones consisted of 145 individuals.

We also restimated our indices by educational level rather than detailed group within levels in Table 4. As can be seen there was significant segregation in Lower and Intermediate Vocational Levels, Primary Education, and Lower General Secondary Education in 1991. While the level of segregation had fallen in all three categories by 2004, it has only become insignificant in Lower General Secondary Education. Clearly, however, as can be seen from Table 3, using these more aggregate groups hides considerable heterogeneity within levels.

\section{Occupational Segregation by Group}

Measuring the impact of ES on OS at the aggregate level as in Table 1 can of course mask heterogeneous experiences across occupations. In order to investigate this we calculated relative OS measures for our occupational categories and the role of ES in these in Table 5 for

13 For example, Davidson and Hinkely (2003) note that consistency is guaranteed when the sample size becomes very large. 
the beginning and end of our sample period. This exercise shows indeed that segregation is not a homogenous characteristic across our occupational groups. For instance, in 1991 there was no significant occupational segregation in Construction and Installation Trades at the Lower Level, in Food and Beverages at the Intermediate Level, and in Medical and Paramedical for Higher Level Occupations. ${ }^{14}$ However, for all of these, except Sales and Purchasing at the Lower and Intermediate Level, and Construction and Installation in Higher Level Occupations, became significantly segregated by 2004. Additionally, a number of previously segregated occupations became unsegregated (in the statistical sense). For instance, Printing Industry from the Lower Level, Artistic Design Trades from the Intermediate Level, and Air and Marine Transport from the Higher Level Occupational Group.

Table 5 also shows that there is significant educational segregation in all of the occupations except Constructions and Installation in the Higher Level Professions in 1991. While the latter occupation group did become educationally segregated by 2004, educational segregation was meanwhile eliminated in the Mechanical and Computing and Electrical and Engineering Higher Level Professions.

Of particular interest is of course the link between ES and OS. Here one should note that in 1991 in all Lower Level Occupations, except in Food and Beverage and Sales and Purchasing jobs, the impact of ES on OS has been very high and statistically significant and that by 2004 the impact was significant for all. In contrast, in the Intermediate Level Occupations for about one third there was no impact, although by 2004 the number of non-significant ones was reduced by a half. Similarly in 1991 about a third of Higher Level Occupations experienced no significant impact of ES on OS. However, by 2004 ES segregation became a significant factor, while at the same time in four categories its effect disappeared. Thus, our disaggregated

${ }^{14}$ As for the educational groups, there appeared to be no relationship between observations within each cell and its statistical significance. 
analysis reveals that, while ES has fallen substantially over our sample period, the remainder of it has become a more important determinant of occupation segregation in contrast to the aggregate figures.

\section{Section V: Conclusion}

We examined the extent of educational and occupational segregation and their link in the context of Trinidad and Tobago over a period in which there was an aggressive policy to reduce educational segregation. Our results show that while segregation in education has fallen substantially, this movement towards equality has not translated into less occupational segregation. Examining segregation at a more disaggregated level shows that there is considerable heterogeneity both in terms of education and occupation, where in some cases men and women are equally represented. However, for many groups there have also been considerable changes over time. Ultimately, at the disaggregated level, the link between educational choice and sorting by gender in employment seems on average strongest and most consistent in the lower occupations. For the other higher level categories there is in contrast much less stability.

Arguably our results have important implications in terms of appropriate policies to combat occupational segregation in the developing countries' labour markets. From a more general perspective it seems not enough to ensure educational equality among men and women, as, at least in Trinidad and Tobago, greater equality in human capital has not ensured greater equality in employment opportunities. One may want to note in this regard that this does not necessarily mean that educational policies in Trinidad were unsuccessful in reducing occupational segregation, since there my have been other concurrent factors increasing the degree of gender inequality in employment. In other words, occupational segregation may have 
been higher if there had been no such policies in place. Nor can one decisively conclude that it was indeed the implemented policy that was driving most of the fall in educational segregation, as, again, other factors, may have played a role in this - although given that we are unaware of any other important changes at the time and that the policy guidelines were fairly detailed and aggressively implemented, one may be fairly confident that the policy did play an important role. Nevertheless, worryingly, the impact of segregation in education seems most important for inequality in occupation for the lowest level jobs. However, the evidence also suggests, reassuringly, that even occupational segregation is not necessarily static over time.

\section{References}

Anker, R. and Hein, C. (1986). Sex Inequality in Urban Employment in the Third World. London: Macmillan.

Blau, F. and Ferber, M. (1992). The Economics of Women, Men, and Work. Englewood Cliffs, New Jersey: Prentice-Hall.

Boisso, D., Hayes, K., Hirschberg, J. and Silber, J. (1994). Occupational segregation in the multidimensional case: decomposition and tests of significance. Journal of Econometrics, 61, 16171.

Borghans, L. and Groot, L. (1999). Educational Presorting and Occupational Segregation. Labour Economics, 6, 375-395.

Davidson, A. and Hinkley, D. (2003). Bootstrap Methods and their Applications. Cambridge Series in Statistical and Probabilistic Mathematics, No 1. Cambridge: Cambridge University Press.

Deutsch, R. Morrison, A. Piras, C. and Nopo, H. (2001). Working Within Confines: Occupational Segregation by Gender for Three Latin American Countries. Sustainable Development Department Technical Papers Series, Washington D.C.: Inter-American Development Bank.

Dolado, J. Felguerose, F., and Jimeno, J. (2004). Where to Women Work? Analysing Patterns in Occupational Segregation by Gender. Annales d'Economie et de Statistique, 71-72, 295-315.

Duncan, B. and Duncan, O.D. (1955). A Methodological Analysis of Segregation Indices. American Sociological Review, 20, 210-217. 
Gammage, S. (1998). La Dimension de Genero en la Pobreza, la Desigualdad y la Reforma macroeconomica en America Latina. In: Politica Economica y Porbreza en America Latina y el Caribe, Washington, D.C.: PNUD, CEPAL, IDB.

National Report on the Development of Education in Trinidad and Tobago. (2004). Ministry of Education: Trinidad and Tobago.

Olsen, R. and Coppin, A. (2001). The Determinants of Gender Differences in Income in Trinidad and Tobago. Journal of Development Studies, 5, 31-56.

Scholz, F. (2007). The Bootstrap Small Sample Properties. Mimeo, University of Washington: Seattle, Washington.

World Bank (2003). Gender Equality and the Millenium Development Goals. Gender and Development Group. World Bank: Washington, D.C. 
Table 1: Aggregate Results

\begin{tabular}{|ccccccc}
\hline Year & $\begin{array}{c}\text { Occupational } \\
\text { Segregation }\end{array}$ & $\begin{array}{c}\text { Educational } \\
\text { Segregation }\end{array}$ & Increase & Decrease (-) & Reintegration (-) \\
\hline 1991 & $26.517(0.420)^{* *}$ & $23.076(0.519)^{* *}$ & $12.034(0.428)^{* *}$ & $4.217(0.139)^{* *}$ & $4.376(0.295)^{* *}$ & $81.037(1.256)^{* *}$ \\
1992 & $28.030(0.657)^{* *}$ & $21.417(0.710)^{* *}$ & $14.710(0.654)^{* *}$ & $4.144(0.196)^{* *}$ & $3.953(0.424)^{* *}$ & $81.541(1.941)^{* *}$ \\
1993 & $27.701(0.757)^{* *}$ & $21.348(0.837)^{* *}$ & $14.766(0.690)^{* *}$ & $4.167(0.236)^{* *}$ & $4.246(0.516)^{* *}$ & $80.110(2.418)^{* *}$ \\
1994 & $24.794(0.448)^{* *}$ & $14.636(0.490)^{* *}$ & $15.925(0.483)^{* *}$ & $3.454(0.160)^{* *}$ & $2.313(0.242)^{* *}$ & $84.196(1.743)^{* *}$ \\
1995 & $24.755(0.469)^{* *}$ & $13.904(0.500)^{* *}$ & $16.567(0.517)^{* *}$ & $3.370(0.160)^{* *}$ & $2.346(0.235)^{* *}$ & $83.129(1.794)^{* *}$ \\
1996 & $24.565(0.542)^{* *}$ & $13.786(0.647)^{* *}$ & $16.439(0.615)^{* *}$ & $3.354(0.234)^{* *}$ & $2.306(0.257)^{* *}$ & $83.272(2.058)^{* *}$ \\
1998 & $24.420(0.481)^{* *}$ & $13.656(0.533)^{* *}$ & $16.437(0.498)^{* *}$ & $3.194(0.191)^{* *}$ & $2.479(0.240)^{* *}$ & $81.849(1.845)^{* *}$ \\
1999 & $25.339(0.538)^{* *}$ & $13.508(0.573)^{* *}$ & $17.946(0.604)^{* *}$ & $3.306(0.186)^{* *}$ & $2.809(0.290)^{* *}$ & $79.206(2.454)^{* *}$ \\
2000 & $26.494(0.606)^{* *}$ & $14.399(0.630)^{* *}$ & $17.814(0.678)^{* *}$ & $3.634(0.190)^{* *}$ & $2.085(0.307)^{* *}$ & $85.522(2.165)^{* *}$ \\
2001 & $24.341(0.469)^{* *}$ & $13.216(0.509)^{* *}$ & $16.867(0.513)^{* *}$ & $3.350(0.162)^{* *}$ & $2.391(0.247)^{* *}$ & $81.905(1.969)^{* *}$ \\
2002 & $25.226(0.553)^{* *}$ & $15.186(0.539)^{* *}$ & $16.398(0.559)^{* *}$ & $3.782(0.165)^{* *}$ & $2.575(0.310)^{* *}$ & $83.040(2.025)^{* *}$ \\
2003 & $24.502(0.539)^{* *}$ & $13.271(0.556)^{* *}$ & $17.373(0.585)^{* *}$ & $3.443(0.188)^{* *}$ & $2.699(0.307)^{* *}$ & $79.664(2.507)^{* *}$ \\
2004 & $24.990(0.588)^{* *}$ & $12.796(0.577)^{* *}$ & $17.845(0.574)^{* *}$ & $3.140(0.190)^{* *}$ & $2.511(0.326)^{* *}$ & $80.374(2.636)^{* *}$ \\
\hline
\end{tabular}

Notes: (1) bootstrapped standard errors in parentheses. (2) * significant at $5 \%$; ** significant at $1 \%$. (3) Index values are given in percentage terms. 
Table 2: Summary Trends by Educational Group

\begin{tabular}{|c|c|c|}
\hline Educational Group & 1991 & 2004 \\
\hline Primary Education & 15.2 & 34.9 \\
\hline Lower General Secondary Education & 24.3 & 39.1 \\
\hline \multicolumn{3}{|l|}{ Higher General Secondary Education } \\
\hline Craft and Industry and Technical & 25.0 & 60.0 \\
\hline Service & 100.0 & \\
\hline \multicolumn{3}{|l|}{ Lower Vocational Education } \\
\hline Commerce and Administration & 87.0 & 82.3 \\
\hline Technical and Service & 21.6 & 21.6 \\
\hline Agriculture & 0.0 & 12.5 \\
\hline Hotel, Catering and Tourism & 70.0 & 76.5 \\
\hline Auxiliary Health-Related & 100.0 & 100.0 \\
\hline \multicolumn{3}{|l|}{ Intermediate Vocational Education } \\
\hline Social Work, Counceling and Physical Education & 69.6 & 64.2 \\
\hline Transport and Communication & 14.3 & 30.8 \\
\hline Police, Fire and Defense Forces & 5.3 & 13.0 \\
\hline Commerce and Administration & 39.3 & 57.4 \\
\hline Agriculture and Environment & 10.2 & 12.5 \\
\hline Technical, Medical and Non-Medical Laboratory & 53.9 & 64.6 \\
\hline Engineering & 4.1 & 2.9 \\
\hline Nursing and Para-Medical Services & 84.8 & 93.5 \\
\hline Administrative, Legal and Fiscal & 71.3 & 76.1 \\
\hline Hotel, Catering and Tourism Services & 82.7 & 70.0 \\
\hline \multicolumn{3}{|l|}{ Higher Vocational Education } \\
\hline Social Work and Counseling & & 100.0 \\
\hline Teacher Training & 51.9 & 75.5 \\
\hline Religion and Theology & 0.0 & 0.0 \\
\hline Agriculture and Environment & 16.7 & 57.1 \\
\hline Non-medical and Medical Laboratory & 33.3 & 41.9 \\
\hline Engineering & 0.0 & 10.0 \\
\hline Medical and Non-Medical & 15.0 & 43.8 \\
\hline Nursing, Physiotherapy and Occupational Therapy & & 66.7 \\
\hline Administrative and Legal & 34.8 & 53.8 \\
\hline Management and Public administration & 35.0 & 51.9 \\
\hline Fine and Applied Arts & 75.8 & 69.4 \\
\hline \multicolumn{3}{|l|}{ Academic Education } \\
\hline Teacher Training & 100.0 & 100.0 \\
\hline Arts, Humanity and Education & & 100.0 \\
\hline Natural Sciences & & 0.0 \\
\hline Engineering & & 0.0 \\
\hline Medical Sciences, Dentistry and Veterinary Sciences & 0.0 & 66.7 \\
\hline Social Sciences & 0.0 & 57.1 \\
\hline Law and Public Adminstration & & 50.0 \\
\hline Business Administration and Management & 100.0 & 75.0 \\
\hline Fine Arts & & 100.0 \\
\hline Social Work, Counseling and Physical Education & & 100.0 \\
\hline
\end{tabular}


Table 3: ES by Educational Group

\begin{tabular}{|c|c|c|}
\hline Educational Groups & 1991 & 2004 \\
\hline Primary Education: & $-18.832(0.700)^{* *}$ & $-5.795(0.722)^{* *}$ \\
\hline Lower General Secondary Education: & $-9.702(1.208)^{* *}$ & $-1.541(0.954)$ \\
\hline \multicolumn{3}{|c|}{ Lower Vocational Education (Individuals with a O'Levels and a Vocation): } \\
\hline Commerce and Administration & $53.044(1.175)^{* *}$ & $41.677(2.165)^{* *}$ \\
\hline Technical and Service & $-12.419(1.100)^{* *}$ & $-19.024(1.493)^{* *}$ \\
\hline Agriculture & $-33.997(0.504)^{* *}$ & $-28.156(10.771)^{* *}$ \\
\hline Hotel, Catering and Tourism & $36.003(4.983)^{* *}$ & $35.814(4.964)^{* *}$ \\
\hline Auxiliary Health-Related & $66.003(0.504)^{* *}$ & $59.344(0.515)^{* *}$ \\
\hline \multicolumn{3}{|l|}{$\begin{array}{l}\text { Higher General Secondary Education } \\
\text { (individuals with A'levels and Technical Education) }\end{array}$} \\
\hline Craft and Industry and Technical & $-8.997(5.712)$ & $19.344(7.308)^{* *}$ \\
\hline Service & $66.003(0.504)^{* *}$ & \\
\hline \multicolumn{3}{|c|}{ Intermediate Vocational Education (Individuals with A'Levels and an Associate Degree): } \\
\hline Social Work, Counseling and Physical Education & $35.593(2.427)^{* *}$ & $23.571(3.311)^{* *}$ \\
\hline Transport and Communication & $-19.712(6.316)^{* *}$ & $-9.887(8.959)$ \\
\hline Police, Fire and Defense Forces & $-28.694(1.443) * *$ & $-27.669(3.274)^{* *}$ \\
\hline Commerce and Administration & $5.288(3.719)$ & $16.751(7.628)^{*}$ \\
\hline Agriculture and Environment & $-23.793(3.151)^{* *}$ & $-28.156(5.271) * *$ \\
\hline Technical, Medical and Non-Medical Laboratory & $19.935(3.791)^{* *}$ & $23.927(5.573)^{* *}$ \\
\hline Engineering & $-29.888(1.640)^{* *}$ & $-37.715(1.978)^{* *}$ \\
\hline Nursing and Para-Medical Services & $50.851(2.962)^{* *}$ & $52.822(3.517)^{* *}$ \\
\hline Administrative, Legal and Fiscal & $37.320(2.781)^{* *}$ & $35.431(5.580)^{* *}$ \\
\hline Hotel, Catering and Tourism Services & $48.695(3.450)^{* *}$ & $29.344(9.969)^{* *}$ \\
\hline \multicolumn{3}{|c|}{ Higher Vocational Education (Individuals with a University first degree) } \\
\hline Social Work and Counseling & & $59.344(0.515)^{* *}$ \\
\hline Teacher Training & $17.926(4.980)^{* *}$ & $34.854(5.945)^{* *}$ \\
\hline Religion and Theology & $-33.997(0.504)^{* *}$ & $-40.656(0.515)^{* *}$ \\
\hline Agriculture and Environment & $-17.331(8.954)$ & $16.487(16.909)$ \\
\hline Non-medical and Medical Laboratory & $0.664(3.817)$ & $1.279(4.037)$ \\
\hline Engineering & $-33.997(0.504)^{* *}$ & $-30.656(5.634) * *$ \\
\hline Medical and non-Medical & $-18.997(5.521)^{* *}$ & $3.094(9.691)$ \\
\hline Nursing, Physiotherapy and Occupational Therapy & & $-26.010(22.137)$ \\
\hline Administrative and Legal & $-0.785(4.264)$ & $13.190(11.796)$ \\
\hline Management and Public Administration & $1.003(3.493)$ & $11.292(5.086)^{*}$ \\
\hline Fine and Applied Arts & $41.760(5.371)^{* *}$ & $28.788(9.494)^{* *}$ \\
\hline \multicolumn{3}{|c|}{ Academic Education (Individuals with Post Graduate qualification) } \\
\hline Teacher Training & $66.003(0.504)^{* *}$ & \\
\hline Arts, Humanity and Education & & $59.344(0.515)^{* *}$ \\
\hline \multicolumn{3}{|l|}{ Medical Sciences, Dentistry and Veterinary } \\
\hline Sciences & $-33.997(0.504)^{* *}$ & $-59.344(0.515)^{* *}$ \\
\hline Social Sciences & & $-40.656(0.515)^{* *}$ \\
\hline Law and Public Administration & & $40.656(0.515)^{* *}$ \\
\hline Business Administration and Management & $33.997(0.504)^{* *}$ & \\
\hline Social Work and Counseling & & $26.010(21.954)$ \\
\hline
\end{tabular}

Notes: (1) standard errors in parentheses. (2)* significant at 5\%; ** significant at $1 \%$

(3) Index values are given in percentage terms. 
Table 4: ES by Educational Level

\begin{tabular}{|lcc|}
\hline Education Level & 1991 & 2004 \\
Primary & $-18.8316(0.706)^{* *}$ & $-5.79469(0.739)^{* *}$ \\
Lower General Secondary Education & $-9.7017(1.191)^{* *}$ & $-1.54149(1.189)$ \\
Higher General Secondary Education & $-8.99748(5.661)$ & $19.34368(7.997)$ \\
Lower Vocational Education & $16.09776(0.952)^{* *}$ & $6.364267(1.455)^{* *}$ \\
Intermediate Vocational Education & $13.77629(1.082)^{* *}$ & $8.22876(1.905)^{* *}$ \\
Higher Vocational Education & $5.191711(2.170)$ & $12.3512(3.015)$ \\
Academic Education & $16.00252(14.525)$ & $27.34368(9.428)$ \\
\hline
\end{tabular}

Notes: (1) bootstrapped standard errors in parentheses. (2) * significant at 5\%; ** significant at 1\%. (3) Index values are given in percentage terms. 
Table 5: Occupational Segregation derived from Pre- and Post-Sorting

\begin{tabular}{|c|c|c|c|c|c|c|}
\hline \multirow[b]{2}{*}{ Occupations } & \multicolumn{3}{|c|}{1991} & \multicolumn{3}{|c|}{2004} \\
\hline & $\begin{array}{l}\text { Educational } \\
\text { Segregation }\end{array}$ & $\begin{array}{l}\text { Occupational } \\
\text { Segregation }\end{array}$ & $\begin{array}{c}\text { Impact } \\
(\%)\end{array}$ & $\begin{array}{l}\text { Educational } \\
\text { Segregation }\end{array}$ & $\begin{array}{l}\text { Occupational } \\
\text { Segregation }\end{array}$ & $\begin{array}{c}\text { Impact } \\
(\%)\end{array}$ \\
\hline \multicolumn{7}{|c|}{ Lower Level Occupations (individuals with primary/secondary/vocational education): } \\
\hline $\begin{array}{l}\text { Lower security occupations }{ }^{\mathrm{m}} \\
\text { Lower technical and industrial } \\
\text { occupations }^{\mathrm{m}} \\
\text { Lower administrative occupations } \\
\text { Lower agricultural occupations } \\
\text { Lower food and beverage occupations } \\
\text { Lower textile occupations } \\
\text { Lower wood and paper occupations }^{\mathrm{m}} \\
\text { Lower printing industry occupations }^{\mathrm{m}} \\
\text { Lower chemical industry occupations }^{\mathrm{m}} \\
\text { Lower mining industry occupations }^{\mathrm{m}} \\
\text { Lower construction and installation } \\
\text { occupations } \\
\text { Lower transport occupations }^{\mathrm{m}} \\
\text { Lower marine occupations } \\
\text { Lower road occupations } \\
\text { Lower sales and purchasing occupations }^{\mathrm{m}} \\
\text { Lower hotel and catering occupations } \\
\text { Lower service occupations }\end{array}$ & $\begin{array}{l}27.795(1.675)^{* *} \\
30.737(0.774)^{* *} \\
46.064(1.671)^{* *} \\
23.657(1.692)^{* *} \\
20.972(4.121)^{* *} \\
40.478(2.499)^{* *} \\
33.996(0.516)^{* *} \\
34.942(7.359)^{* *} \\
27.786(3.233)^{* *} \\
33.996(0.539)^{* *} \\
30.462(0.769)^{* *} \\
33.228(0.806)^{* *} \\
33.997(0.540)^{* *} \\
33.997(0.534)^{* *} \\
14.947(2.984)^{* *} \\
25.944(3.596)^{* *} \\
23.626(1.738)^{* *} \\
\end{array}$ & $\begin{array}{c}25.664(1.806)^{* *} \\
29.162(0.829)^{* *} \\
44.882(1.782)^{* *} \\
18.613(1.827)^{* *} \\
0.664(3.019) \\
40.485(2.503)^{* *} \\
33.997(0.516)^{* *} \\
30.708(8.672)^{* *} \\
20.840(3.834)^{* *} \\
33.997(0.539)^{* *} \\
\\
29.501(0.806)^{* *} \\
31.792(0.975)^{* *} \\
33.997(0.540)^{* *} \\
33.997(0.534)^{* *} \\
1.529(2.573) \\
23.974(4.196)^{* *} \\
22.114(1.782)^{* *} \\
\end{array}$ & $\begin{array}{c}92.323(5.674)^{* *} \\
\\
94.823(1.606)^{* *} \\
97.418(1.355)^{* *} \\
78.669(5.945)^{* *} \\
3.165(13.276) \\
100.00(0.270)^{* *} \\
100.00(0.000)^{* *} \\
87.882(14.036)^{* *} \\
74.996(11.576)^{* *} \\
100.00(0.000)^{* *} \\
\\
96.794(1.596)^{* *} \\
95.662(2.579)^{* *} \\
100.00(0.000)^{* *} \\
100.00(0.000)^{* *} \\
10.238(16.467) \\
92.403(7.851)^{* *} \\
93.604(1.780)^{* *} \\
\end{array}$ & $\begin{array}{c}16.636(3.463)^{* *} \\
31.188(1.680)^{* *} \\
35.343(2.483)^{* *} \\
24.441(2.485)^{* *} \\
10.717(6.668) \\
36.889(4.184)^{* *} \\
38.154(2.555)^{* *} \\
7.612(8.530)^{*} \\
39.006(2.858)^{* *} \\
40.655(0.762)^{* *} \\
\\
30.619(1.290)^{* *} \\
38.125(1.053)^{* *} \\
40.656(0.718)^{* *} \\
37.529(2.409)^{* *} \\
6.234(2.921)^{* *} \\
38.149(3.197)^{* *} \\
19.932(1.652)^{* *} \\
\end{array}$ & $\begin{array}{c}13.944(3.660)^{* *} \\
30.344(1.764)^{* *} \\
32.524(2.613)^{* *} \\
23.773(2.532)^{* *} \\
9.344(6.839) \\
36.895(4.185)^{* *} \\
38.156(2.555)^{* *} \\
4.942(8.060) \\
32.762(4.260)^{* *} \\
40.656(0.762)^{* *} \\
\\
29.014(1.357)^{* *} \\
37.616(1.155)^{* *} \\
40.656(0.718)^{* *} \\
37.531(3.048)^{* *} \\
4.406(3.173) \\
36.741(3.474)^{* *} \\
19.272(1.638)^{* *} \\
\end{array}$ & $\begin{array}{c}83.802(11.137)^{* *} \\
97.247(2.127)^{* *} \\
91.996(3.380)^{* *} \\
97.236(2.887)^{* *} \\
87.188(28.597)^{* *} \\
100.00(0.000)^{* *} \\
100.00(0.000)^{* *} \\
64.927(31.954)^{*} \\
83.985(10.508)^{* *} \\
100.00(0.000)^{* *} \\
\\
94.665(2.035)^{* *} \\
98.617(1.380)^{* *} \\
100.00(0.000)^{* *} \\
100.00(4.755)^{* *} \\
70.682(27.882)^{* *} \\
96.291(3.792)^{* *} \\
96.604(2.017)^{* *}\end{array}$ \\
\hline \multicolumn{7}{|c|}{ Intermediate Level Occupations (Individuals with higher secondary level education/technical education/ university first degree): } \\
\hline $\begin{array}{l}\text { Intermediate police, fire and military } \\
\text { occupations }^{\mathrm{m}} \\
\text { Intermediate teaching professions } \\
\text { Intermediate medical and paramedical } \\
\text { professionals } \\
\text { Intermediate technical and industrial } \\
\text { trades }^{\mathrm{m}}\end{array}$ & $\begin{array}{l}26.986(1.334)^{* *} \\
41.998(2.248)^{* *} \\
50.535(3.168)^{* *} \\
28.402(1.608)^{* *}\end{array}$ & $\begin{array}{l}25.571(1.567)^{* *} \\
40.866(2.349)^{* *} \\
46.003(3.694)^{* *} \\
26.590(1.878)^{* *}\end{array}$ & $\begin{array}{l}94.753(3.710)^{* *} \\
97.294(1.432)^{* *} \\
91.030(3.392)^{* *} \\
93.610(4.101)^{* *}\end{array}$ & $\begin{array}{l}32.564(2.929)^{* *} \\
35.178(3.334)^{* *} \\
54.343(2.929)^{* *} \\
38.088(1.783)^{* *}\end{array}$ & $\begin{array}{l}27.911(3.241)^{* *} \\
32.592(3.626)^{* *} \\
54.344(3.338)^{* *} \\
32.085(2.828)^{* *}\end{array}$ & $\begin{array}{l}85.707(6.850)^{* *} \\
92.639(3.983)^{* *} \\
100.00(2.871)^{* *} \\
84.227(7.408)^{* *}\end{array}$ \\
\hline $\begin{array}{l}\text { Intermediate mechanical and computing } \\
\text { industry trades } \\
\text { Intermediate electrical, electronic and } \\
\text { chemical trades }^{\mathrm{m}}\end{array}$ & $\begin{array}{l}23.732(4.051)^{* *} \\
21.214(3.023)^{* *}\end{array}$ & $\begin{array}{c}10.664(5.215)^{* *} \\
12.429(3.864)\end{array}$ & $\begin{array}{l}44.935(21.173)^{*} \\
58.586(16.408)^{* *}\end{array}$ & $\begin{array}{l}29.576(3.357)^{* *} \\
34.176(3.164)^{* *}\end{array}$ & $\begin{array}{l}23.990(5.436)^{* *} \\
23.415(5.186)^{* *}\end{array}$ & $\begin{array}{l}81.109(16.131)^{* *} \\
68.508(15.187)^{* *}\end{array}$ \\
\hline
\end{tabular}




\begin{tabular}{|c|c|c|c|c|c|c|}
\hline \multirow[b]{2}{*}{ Occupations } & \multicolumn{3}{|c|}{1991} & \multicolumn{3}{|c|}{2004} \\
\hline & $\begin{array}{l}\text { Educational } \\
\text { Segregation }\end{array}$ & $\begin{array}{c}\text { Occupational } \\
\text { Segregation }\end{array}$ & $\begin{array}{c}\text { Impact } \\
(\%)\end{array}$ & $\begin{array}{l}\text { Educational } \\
\text { Segregation }\end{array}$ & $\begin{array}{c}\text { Occupational } \\
\text { Segregation }\end{array}$ & $\begin{array}{c}\text { Impact } \\
(\%)\end{array}$ \\
\hline $\begin{array}{l}\text { Intermediate artistic and design trades } \\
\text { Intermediate marine occupations }{ }^{\mathrm{m}} \\
\text { Intermediate sport occupations }^{\mathrm{m}} \\
\text { Intermediate construction and installation } \\
\text { trades }^{\mathrm{m}} \\
\text { Intermediate air transport occupations } \\
\text { Intermediate administrative occupations } \\
\text { Intermediate sales and purchasing } \\
\text { occupations } \\
\text { Intermediate hotel and catering } \\
\text { occupations } \\
\text { Intermediate service occupations } \\
\text { Intermediate agricultural professions } \\
\text { Intermediate social occupations } \\
\text { Intermediate printing occupations }{ }^{\mathrm{m}} \\
\end{array}$ & $\begin{array}{l}23.828(3.300)^{* *} \\
33.997(0.552)^{* *} \\
33.997(4.938)^{* *} \\
21.075(9.244)^{*} \\
38.667(8.084)^{* *} \\
40.301(5.282)^{* *} \\
\\
22.800(4.468)^{* *} \\
33.997(2.402)^{* *} \\
31.142(6.277)^{* *} \\
37.553(4.264)^{* *} \\
45.999(4.806)^{* *} \\
38.569(8.516)^{* *} \\
\end{array}$ & $\begin{array}{c}11.140(5.014)^{*} \\
33.997(0.552)^{* *} \\
33.997(8.237)^{* *} \\
10.921(8.203) \\
16.003(13.384) \\
36.624(10.607)^{* *} \\
\\
2.003(10.403) \\
33.997(10.111)^{* *} \\
1.717(7.863) \\
22.886(8.832)^{* *} \\
3.503(9.469) \\
19.712(13.628) \\
\end{array}$ & $\begin{array}{c}46.751(20.889)^{*} \\
100.00(0.000)^{* *} \\
100.00(19.373)^{* *} \\
51.818(28.699) \\
41.385(28.049) \\
90.861(23.861)^{* *} \\
\\
8.784(30.212) \\
100.00(29.519)^{* *} \\
5.513(22.494) \\
60.943(26.806)^{*} \\
7.614(23.675) \\
51.107(26.888) \\
\end{array}$ & $\begin{array}{c}22.275(5.712)^{* *} \\
40.656(4.167)^{* *} \\
32.525(6.112)^{* *} \\
40.656(0.711)^{* *} \\
40.656(2.054)^{* *} \\
37.893(8.608)^{* *} \\
18.608(8.392)^{*} \\
29.180(7.838)^{* *} \\
37.50(9.708)^{* *} \\
20.219(14.051) \\
54.672(11.642)^{* *} \\
27.475(14.703) \\
\end{array}$ & $\begin{array}{c}10.353(6.791) \\
40.656(12.223)^{* *} \\
20.656(12.918) \\
40.656(0.711)^{* *} \\
40.656(2.442)^{* *} \\
37.195(13.060)^{* *} \\
11.445(6.223) \\
7.323(9.895) \\
3.156(10.181) \\
7.323(18.233) \\
34.344(19.074) \\
19.344(13.649) \\
\end{array}$ & $\begin{array}{c}46.477(25.343) \\
100.00(29.208)^{* *} \\
63.509(31.325)^{*} \\
100.00(0.000)^{* *} \\
100.00(1.754)^{* *} \\
98.118(25.089)^{* *} \\
61.50(23.448)^{* *} \\
25.095(25.562) \\
8.416(27.983) \\
36.219(31.159) \\
62.818(30.708)^{*} \\
70.404(28.942)^{* *}\end{array}$ \\
\hline \multicolumn{7}{|c|}{ Higher Level Professions (Individuals with postgraduate qualifications): } \\
\hline $\begin{array}{l}\text { Higher natural and life sciences } \\
\text { professions } \\
\text { Higher administrative professions } \\
\text { Higher legal and government professions } \\
\text { Higher teaching professions } \\
\text { Higher medical and paramedical } \\
\text { professions }{ }^{\mathrm{m}} \\
\text { Higher theological vocations }^{\mathrm{m}} \\
\text { Higher air transport and marine transport }^{\text {occupations }} \mathrm{s}^{\mathrm{m}}\end{array}$ & $\begin{array}{c}60.668(15.884)^{* *} \\
18.937(4.406)^{* *} \\
6.891(7.239) \\
25.245(4.227)^{* *} \\
\\
22.798(6.358)^{* *} \\
17.331(7.366)^{* *} \\
33.997(1.849)^{* *} \\
\end{array}$ & $\begin{array}{c}49.336(20.903)^{* *} \\
1.322(2.931) \\
0.664(6.142) \\
18.705(4.781)^{* *} \\
13.997(7.252) \\
17.331(10.288) \\
33.997(7.783)^{* *} \\
\end{array}$ & $\begin{array}{l}81.320(30.321)^{* *} \\
6.987(25.068) \\
9.636(31.976) \\
74.095(13.688)^{* *} \\
61.398(25.220)^{* *} \\
100.00(31.470)^{* *} \\
100.00(23.004)^{* *} \\
\end{array}$ & $\begin{array}{c}8.606(11.449) \\
27.137(10.108)^{* *} \\
24.506(8.969)^{* *} \\
13.383(13.441) \\
40.656(5.561)^{* *} \\
34.890(7.554)^{* *} \\
31.776(7.214)^{* *} \\
\end{array}$ & $\begin{array}{c}3.864(12.808) \\
20.882(11.023) \\
21.046(9.154)^{* *} \\
13.384(14.200) \\
40.656(15.587)^{* *} \\
1.010(10.172) \\
1.010(11.126) \\
\end{array}$ & $\begin{array}{c}44.952(30.085) \\
76.951(24.296)^{* *} \\
85.881(21.129)^{* *} \\
100.00(25.337)^{* *} \\
100.00(37.881)^{* *} \\
2.895(24.187) \\
3.178(28.865)\end{array}$ \\
\hline $\begin{array}{l}\text { Higher technical and industrial } \\
\text { professions }^{\mathrm{m}} \\
\text { Higher mechanical and computing industry }_{\text {professions }^{\mathrm{m}}} \\
\text { Higher electrical and engineering } \\
\text { professions }^{\mathrm{m}} \\
\text { Higher construction and installation } \\
\text { professions }^{\mathrm{m}}\end{array}$ & $\begin{array}{l}35.998(4.382)^{* *} \\
36.152(4.289)^{* *} \\
33.997(5.169)^{* *} \\
13.998(12.070)\end{array}$ & $\begin{array}{c}12.569(7.141) \\
10.921(9.855) \\
33.997(7.293)^{* *} \\
13.997(12.853)\end{array}$ & $\begin{array}{c}34.914(23.634) \\
30.206(30.208) \\
100.00(15.421)^{* *} \\
100.00(33.379)^{* *}\end{array}$ & $\begin{array}{l}39.393(10.667)^{* *} \\
26.371(13.509) \\
23.990(16.335) \\
51.868(5.219)^{* *}\end{array}$ & $\begin{array}{c}25.656(10.714)^{* *} \\
26.371(12.835)^{*} \\
23.990(17.056) \\
19.344(21.118)\end{array}$ & $\begin{array}{c}65.127(26.294)^{* *} \\
100.00(18.331)^{* *} \\
100.00(32.922)^{* *} \\
37.293(34.347)\end{array}$ \\
\hline
\end{tabular}




\begin{tabular}{|c|c|c|c|c|c|c|}
\hline \multirow[b]{2}{*}{ Occupations } & \multicolumn{3}{|c|}{1991} & \multicolumn{3}{|c|}{2004} \\
\hline & $\begin{array}{l}\text { Educational } \\
\text { Segregation }\end{array}$ & $\begin{array}{l}\text { Occupational } \\
\text { Segregation }\end{array}$ & $\begin{array}{c}\text { Impact } \\
(\%)\end{array}$ & $\begin{array}{l}\text { Educational } \\
\text { Segregation }\end{array}$ & $\begin{array}{l}\text { Occupational } \\
\text { Segregation }\end{array}$ & $\begin{array}{l}\text { Impact } \\
(\%)\end{array}$ \\
\hline Higher artistic and design professions & $49.501(8.199)^{* *}$ & $41.003(13.489)^{* *}$ & $82.830(21.404)^{* *}$ & $59.343(0.623)^{*}$ & $59.344(0.623)^{* *}$ & $100.00(0.000)^{* *}$ \\
\hline Higher Social Sciences professions ${ }^{m}$ & $39.331(9.593)^{* *}$ & $17.331(18.631)$ & $44.063(32.798)$ & $59.344(0.619)^{* *}$ & $59.344(0.619)^{* *}$ & $100.00(0.000)^{* *}$ \\
\hline Information professions & $66.002(0.533)^{* *}$ & $66.003(0.533)^{* *}$ & $100.00(0.000)^{* *}$ & $16.636(3.463)^{* *}$ & $13.944(3.660)^{* *}$ & $83.802(11.137)^{* *}$ \\
\hline
\end{tabular}

Notes: (1) standard errors in parentheses. (2)* significant at $5 \%$; ** significant at $1 \%$. (3) $\mathrm{m}$ indicates educational overrepresentation of men. (3) Index values are given

in percentage terms. 


\section{APPENDIX}

\section{Definition of $I$ and $D$, and $R$ :}

\section{Table A1}

$$
\begin{aligned}
& F_{i j}^{e d u c}<\min \left(F_{i j}, F_{i j}^{e q u a l}\right) \\
& F_{i j}^{e d u c}<\max \left(F_{i j}, F_{i j}^{\text {equal }}\right) \\
& F_{i j}^{\text {educ }}>\max \left(F_{i j}, F_{i j}^{\text {equal }}\right) \\
& F_{i j}^{e d u c}>\min \left(F_{i j}, F_{i j}^{\text {equal }}\right) \\
& F_{i j}<F_{i j}^{\text {equal }}\left\{\begin{array}{c}
I_{i j}=0 \\
D_{i j=} \frac{F_{i j}-F_{i j}^{e d u c}}{T} .
\end{array}\right. \\
& \left\{\begin{array}{c}
I_{i j}=\frac{F_{i j}^{e d u c}-F_{i j}}{T} \\
D_{i j}=0
\end{array}\right. \\
& \left\{\begin{array}{l}
I_{i j}=\frac{F_{i j}^{\text {equal }}-F_{i j}}{T} \\
D_{i j}=\frac{F_{i j}^{\text {educ }}-F_{i j}^{\text {equal }}}{T .}
\end{array}\right. \\
& F_{i j}>F_{i j}^{e q u a l} \\
& \left\{\begin{array} { c } 
{ I _ { i j } = \frac { F _ { i j } - F _ { i j } ^ { e q u a l } } { T } } \\
{ D _ { i j } = \frac { F _ { i j } ^ { e q u a l } - F _ { i j } ^ { e d u c } } { T . } }
\end{array} \left\{\begin{array}{c}
I_{i j}=\frac{F_{i j}-F_{i j}^{e d u c}}{T .} \\
D_{i j}=0
\end{array}\right.\right. \\
& \left\{\begin{array}{c}
I_{i j}=0 \\
D_{i j}=\frac{F_{i j}^{e d u}-F_{i j}}{T} .
\end{array}\right.
\end{aligned}
$$

where

$F_{i j}^{e d u c}=\frac{F_{i .}}{F_{i .}} T_{i j}$

and

$$
F_{i j}^{\text {equal }}=\frac{F \cdot}{T .} T_{i j}
$$

where $I=\frac{1}{T .} \sum_{i=1}^{n} \sum_{j=1}^{m} I_{i j}$

where $D=\frac{1}{T} \sum_{i=1}^{n} \sum_{j=1}^{m} D_{i j}$

The intuition behind the calculation of $I$ and $D$ is as follows. In essence it involves comparing $F_{i j}$, i.e., the actual number of females in education category $i$ working in occupation $j$, with $F_{i j}^{e d u c}$, i.e., the required number of females in education category $i$ working in occupation $j$ so that students from one type of education are distributed over all 
occupations in proportion to their educational sex rations, and $F_{i j}^{\text {equal }}$, i.e., the required number of females in education category $i$ working in occupation $j$ so that women are distributed only according to their overall ratio. The distance between $F_{i j}^{e d u c}$ and $F_{i j}^{\text {equal }}$ can be thought of as presorting in the sense that it measures how far a distribution according to educational sorting is away from what that would be equal to the distribution of women to men in employment. In a similar manner, the distance between $F_{i j}^{e d u c}$ and $F_{i j}$ is a measure of postsorting in comparing the actual distribution of women in an education/occupation cell with that which would correspond to their educational shares. With this in mind, one should note that Table A1 provides six possible orderings of $F_{i j}^{e q u a l}, F_{i j}^{e d u c}$, and $F_{i j}$. The first row corresponds to situations where women are under-represented, while the second row refers to when they are over-represented relative to a distribution that was just equal to their overall ratio in the labour force (weighted by the total number of jobs filled by individuals with the same educational background). Each of these possibilities can then be identified as either moving towards, $I$, and/or moving away from a completely 'equal' distribution, $D$.

$R$ is defined as:

$R=2 \min \left\{\sum_{i=1}^{n} \max \left\{\left(\frac{F_{i j}}{T .}-\frac{F_{i j}^{\text {equal }}}{T .}\right), 0\right\}, \sum_{i=1}^{n} \max \left\{\left(\frac{M_{i j}}{T .}-\frac{M_{i j}^{\text {equal }}}{T .}\right), 0\right\}\right\}$

This equation essentially involves comparing the extent to which the female distribution within education/occupation cells lies above the equal distribution compare to the extent to which the male distribution within education/occupation cells lies above its equal distribution. The lower of these then constitutes the extent of reintegration, $R$. 